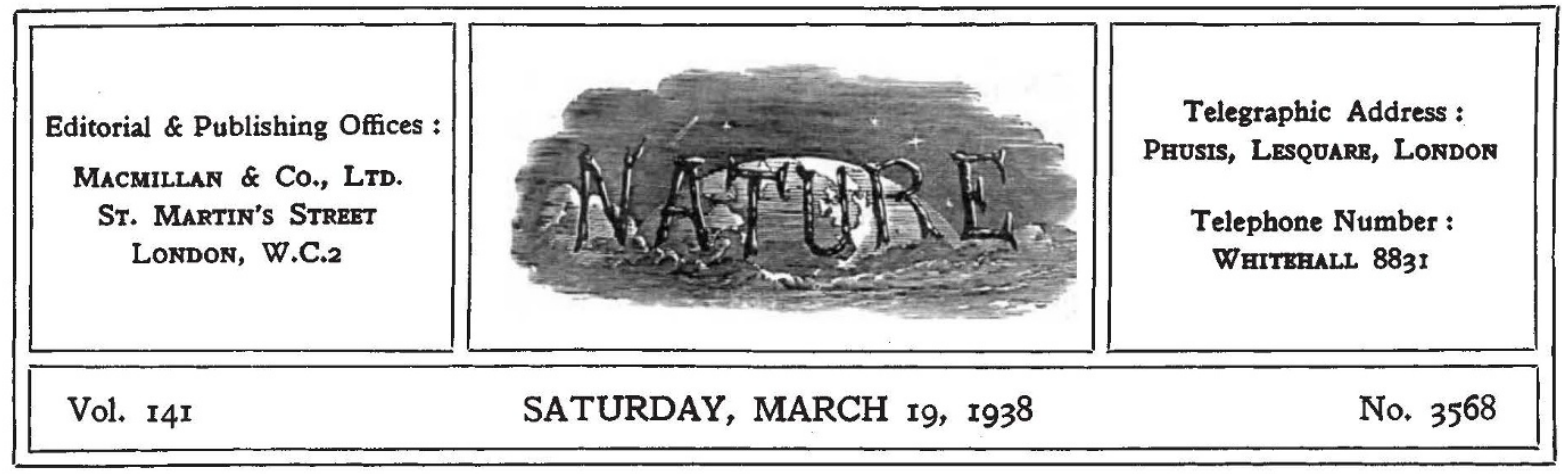

\title{
An Educated Democracy
}

A MONG the social services which have undergone remarkable developments in Great Britain during the present century is that of education, and particularly of secondary education since the passing of the Education Act of 1902. The actual and potential changes in the structure of society brought about by these expansions of educational opportunity are far-reaching, yet it may be doubted whether their significance is generally appreciated. This is the view of Mr. G. A. N. Lowndes, who in a recent work with an arresting title* says: "Nothing is more exasperating to those to whom social reform is religion in action than the readiness with which the English neglect, forget or minimize their achievements." Mr. Lowndes recalls and appraises those achievements in the field of public education, elementary, secondary and technical, in the past forty years, thanks to which Great Britain, it is claimed, is becoming "an educated democracy". Some of the most telling in the series of contrasts through which the magnitude of these achievements is presented illustrate the progress of secondary education-progress which has been rightly characterized as 'revolutionary' by statesmen and historians.

The secondary school population has quadrupled. and now includes 350,000 former pupils of public elementary schools. In 1934 the proportion of elementary school pupils, aged 10-11, passing into secondary schools was 119 per thousand, whilst in $\mathbf{1 8 9 5}$ the corresponding proportion (elementary school leavers passing on to endowed grammar schools) was probably not more than 3-6 per

* P. 236 of "The Silent Social Revolution : an Account of the Expansion of Public Education in England and Wales, 1895-1935". By G. A. N. Lowndes. Pp. xii $+274+8$ plates. (London : Oxford University Press, 1937.) 68, net. thousand. Forty years ago the number of pupils holding county and county borough scholarships at schools of secondary type was 2,414 , as compared with the 224,981 total, and 23,188 partial, exemptions from payment of fees in grant-aided secondary schools in 1934.

These figures indicate an appreciable advance towards that elusive goal-equal educational opportunity for equal abilities. A similar advance is discernible when one turns to statisties of the output from the grant-aided secondary schools to the universities. Of the 4,192 students who passed from those schools to universities in 1934 (London 1,040, Wales 613, Cambridge 463, Oxford 382 , other universities 1,694$), 1,983$ of the men and 831 of the women had begun their education in elementary schools; 2,209 had paid no fees. Comparable statistics of forty years ago are not given, but Mr. Lowndes recalls a reply given by a witness examined by the Cross Enquiry Commission in $\mathbf{1 8 8 8}$ to a question as to the prospects of a public elementary school pupil ever reaching a university: "It would be next to expecting a boy out of the London Board Schools to take wings . . .", and adds "He was right."

The output from the grant-aided secondary schools to the universities has been a subject of comment in the Board of Education's reports since 1924, when in the course of a comprehensive review of secondary education attention was directed to the rapid increase of this output between 1909 and 1921 from 1,056 to 2,888, chiefly ex-public elementary school pupils. The following year the Board remarked: "It is commonly assumed that a secondary school provides an avenue to the university, at any rate for able pupils. Fifteen years ago this assumption was 
not generally warranted." In 1909-10 about 400 out of 950 schools on the grant list sent one or more pupils to the university. By 1924 there were very few that did not at least occasionally send one. In 1932 the output to the universities had increased to 4,560 and since then the numbers have declined, the total in 1935-36 being 3,578.

The position in regard to assisted students in the universities was reviewed by the University Grants Committee in the last quinquennial report (for 1929-30 to 1934-35). The Committee emphasizes the extent to which the approach to the universities is made possible by scholarships, maintenance allowances, or eleemosynary grants. At least $£ 1,350,000$ is spent in this way annually by Government departments, local education authorities, universities, Oxford and Cambridge colleges and the trustees of public endowments in Great Britain. The Committee adds that fifty per cent of the students in the provincial universities began their education in public elementary schools. In further illustration of the same point may be cited, from the Board of Education's report for 1935-36, the fact that out of 719 open scholarships at Oxford and Cambridge 374 were won by pupils at the grant-aided secondary schools, of whom nearly three fourths had paid no fees and two thirds had been previously educated in public elementary schools.

The contribution of the grant-aided secondary schools to the universities is really greater than that represented by the Board's statistics already mentioned, because these exclude the considerable number of students who enter universities after an interval instead of proceeding immediately from school. The number so excluded was estimated by the Board in 1925 to have been about ten per cent; according to Mr. Lowndes, twenty per cent is nearer the mark. Assuming the intake of the universities from this source to be between four and five thousand, how does this compare with the intake from other sources? The total of admissions into the universities of England and Wales is about twelve thousand, of whom about ten per cent are from outside the British Isles. Whence come the remainder, from six to seven thousand, who do not come from the grant-earning secondary schools? With very few exceptions, from the other secondary schools. The grant-aided schools account, according to an estimate in the University Grants Committee's report, for five sixths of the whole secondary school population. The estimate is perhaps a high one, but it seems plain that more than a moiety of the influx of students is from a comparatively small catchment area.

This state of affairs is, of course, associated with that dual system of which Lord Baldwin declared in 1929 "the interests of social unity demand the removal of this source of class prejudice", but which seems immune to the equalitarian influences of the "silent social revolution". Its most obnoxious feature is that, as the authors of "In Defence of Democracy" (Methuen, 1935) put it, it operates to make the consciousness of social difference all pervasive in the working of men's minds in all social and political questions. The success of Rendcombe College goes to show, however, according to Mr. J. H. Nicholson ("Education for Modern Needs": Ivor Nicholson and Watson, 1936) that this feature can be eliminated from the "public schools". Certainly any tendency to divide the community into mutually unintelligible groups is specially to be deplored at a time when a maximum of social unity is needed for meeting the challenge involved in the rise of the powerful and energetic totalitarian régimes.

To that challenge Mr. Lowndes's book makes no reference; nor have the achievements he tells of contributed conspicuously towards generating that active vigorous eitizenship in harmony with democratic principles which is indispensable for their maintenance. The sectional loyalties fostered in so many of our schools are not enough, and wider views will have to be taken if education is to provide a firm basis for constructive democracy.

During the past four years, much valuable work in this direction has been done by the Association for Education in Citizenship, of which Lord Baldwin has recently accepted the presidency. It seeks "the best methods of educating citizens who are likely to maintain and strengthen our democratic system". Much promising exploratory work has been done in various schools (see the Association's "Experiments in Practical Training for Citizenship"), but it has to be recognized that any training for citizenship before the age of fourteen or fifteen years, when the great majority of citizens of the future leave school, can be but very elementary. The British genius for self-government was evolved in the hard and efficient school of learning by doing in days when every village householder had to do his bit of community service, and training in citizenship for the million must await the acceptance by the nation once again of the burden of national service for all. 